\title{
Current Update of Laboratory Molecular Diagnostics Advancement in Management of Colorectal Cancer (CRC)
}

\author{
Siew-Wai Pang ${ }^{1, *}$, Noel Jacques Awi ${ }^{1}$, Subasri Armon ${ }^{2}{ }^{1}$, Wendy Wan-Dee Lim ${ }^{3}$, \\ John Seng-Hooi Low ${ }^{3}$, Kaik-Boo Peh ${ }^{4}$, Suat-Cheng Peh ${ }^{1,3}$ and Sin-Yeang Teow 1 ,*(D) \\ 1 Department of Medical Sciences, School of Healthcare and Medical Sciences, Sunway University, \\ Jalan Universiti, Bandar Sunway, Subang Jaya 47500, Malaysia; 17037854@imail.sunway.edu.my (N.J.A.); \\ pehsc@sunway.edu.my (S.-C.P.) \\ 2 Pathology Department, Hospital Kuala Lumpur, Jalan Pahang, Kuala Lumpur 50588, Malaysia; \\ sarmon2003@gmail.com \\ 3 Sunway Medical Centre, Jalan Lagoon Selatan, Bandar Sunway, Subang Jaya 47500, Malaysia; \\ wendylwd@sunmed.com.my (W.W.-D.L.); johnlsh@sunmed.com.my (J.S.-H.L.) \\ 4 Mahkota Medical Centre, Mahkota Melaka, Jalan Merdeka, Melaka 75000, Malaysia; kbpeh98@hotmail.com \\ * Correspondence: 15035363@imail.sunway.edu.my (S.-W.P.); ronaldt@sunway.edu.my (S.-Y.T.); \\ Tel.: +60-17-621-6191 (S.-W.P.); +60-37-491-8622 (ext. 7449) (S.-Y.T.)
}

Received: 26 September 2019; Accepted: 23 November 2019; Published: 23 December 2019

\begin{abstract}
Colorectal cancer (CRC) continues to be one of the most common cancers globally. The incidence has increased in developing countries in the past few decades, this could be partly attributed to aging populations and unhealthy lifestyles. While the treatment of CRC has seen significant improvement since the advent of target-specific therapies and personalized medicine, CRC is oftentimes detected at late or advanced stages, thereby reducing the efficacy of treatment. Hence, screening for early detection is still the key to combat CRC and to increase overall survival (OS). Considering that the field of medical diagnostics is moving towards molecular diagnostics, CRC can now be effectively screened and diagnosed with high accuracy and sensitivity. Depending on the tumor genotype and genetic profile of the individual, personalized treatments including tyrosine kinase inhibitor therapy and immunotherapy can be administered. Notably, there can be no one single treatment that is effective for all CRC patients due to the variation in tumor genetics, which highlights the importance of molecular diagnostics. This review provides insights on therapeutic modalities, molecular biomarkers, advancement of diagnostic technologies, and current challenges in managing CRC.
\end{abstract}

Keywords: colorectal cancer; molecular; diagnostics; biomarker; technologies; personalized medicine; therapy; genetic; screening; challenges

\section{Colorectal Cancer (CRC) and Its Treatment}

Colorectal cancer $(\mathrm{CRC})$ is one of the most common cancers worldwide, ranking third and second for men and women, respectively. In 2018, Global Cancer Observatory (GLOBOCAN) estimated more than 1.8 million new CRC cases worldwide [1]. There are various therapeutic modalities for CRC depending on the pathological characteristics of the tumor. Laparoscopic surgery is normally carried out for early-stage primary disease, open surgery tumor resection for cases with metastases, and adjuvant radiotherapy for nonresectable cases. Other CRC therapies are neoadjuvant and palliative chemotherapies [2,3], immunotherapy [4], and tyrosine kinase inhibitor (TKI) therapy [5]. The advent of checkpoint inhibitors made of monoclonal antibodies (mAbs) have been a breakthrough for the 
treatment of several cancers including CRC [6]. The safety profile and its efficacy in treating certain CRC patient populations have led to multiple clinical trials. Figure 1 summarizes the list of CRC treatments reviewed according to their date of application or approval by the Food and Drug Administration (FDA) [7-17]. Despite advances in medical and surgical treatment, the long-term survival rates have not improved much [18]. One of the ways in which CRC can be treated optimally is through the elucidation of individual genetic profiles for personalized therapies or precision medicine. Since CRC has several tumor subtypes with complex mutations and genetic variations, treatment decision supported by molecular testing results can dramatically improve the survival rate [19]. The details and specifications of the genes will be discussed in the next section. With advancement of DNA sequencing technologies such as next-generation sequencing (NGS), it is optimistic that precision medicine may be more accessible and affordable, thereby improving clinical outcomes. The sub-sections below will discuss the current treatment methods for CRC.

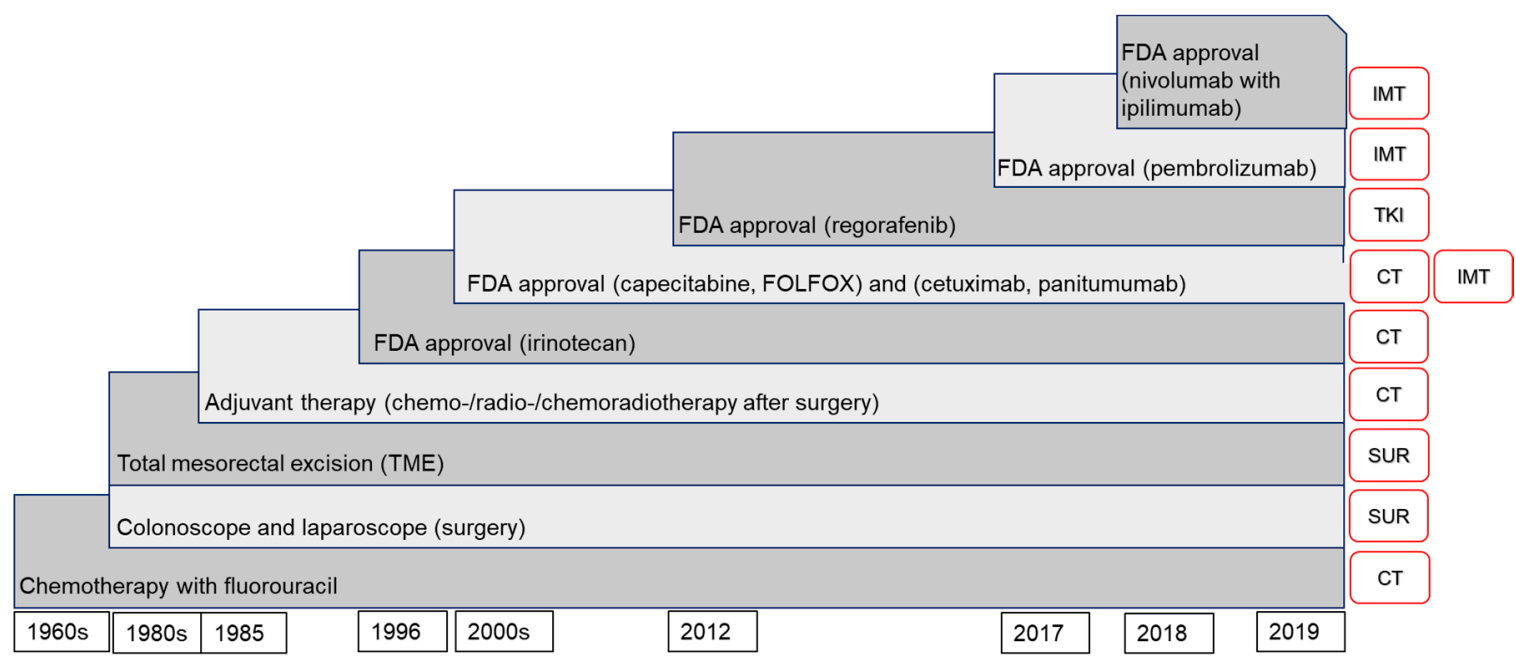

Figure 1. Simplified timeline of colorectal cancer (CRC) treatment options reviewed. The timeline is not constructed according to scale. The red boxes on the right represent the type of treatment, where $\mathrm{CT}=$ chemotherapy, SUR = surgery, IMT = immunotherapy, TKI = tyrosine kinase inhibitor.

\section{Molecular Biomarkers}

Molecular biomarker is an umbrella term for all biomarkers that can be measured based on the biomarker's molecular characteristic. The detection of biomarkers has been the backbone for screening and diagnostic aid in medical laboratories. They are routinely carried out using patient samples such as tissue biopsy, blood, urine, and other biological samples. One of the most common detection methods used in clinical laboratories is immunohistochemistry (IHC), which detects cellular markers and phenotypes specific to certain diseases through staining with highly specific antibodies [20]. Since IHC can be done on both fresh and formalin-fixed tissues, it serves as a convenient, simple, and cost-effective platform for clinical diagnostics [21]. However, there are several limitations. Although it is not difficult to obtain commercially produced antibodies, there are no standard guidelines for the validation of these antibodies. The interpretation of the slides by pathologists can vary considerably and is affected by how the tissue was processed, stored, and handled. This is exacerbated by the presence of intratumoral biomarker heterogeneity that can cause discordance in the classification of cancer [22]. Furthermore, the lack of standardized guidelines for quantitative and semiquantitative scoring raises concern, especially when it involves clinical decisions. While the American Society of Clinical Oncology (ASCO) and College of American Pathologists (CAP) issued guidelines for the handling of biopsy tissues of breast cancer patients, guidelines for other specimens were not available [23]. At present, most of the emerging biomarkers for CRC are more sensitive and specific as 
they interrogate the disease down to the DNA and RNA level [24]. The sub-sections below will discuss examples of common and potential biomarkers in CRC.

\subsection{Methylated Septin9 (mSEPT9)}

Screening programs for CRC are highly effective [25] as most CRCs develop from premalignant lesions such as adenomas [26]. Traditional screening methods such as fecal occult blood test (FOBT) and fecal immunochemical test (FIT) are routinely used to screen CRC, but are generally low in sensitivity and specificity [27]. Currently, the screening of CRC-related biomarkers such as carcinoembryonic antigen [28] and insulin-like growth factor-1 [29] through liquid biopsy is made more convenient, but still lacks specificity. Thus, efforts were made to detect tumor-specific DNA in the form of circulating free DNA (cfDNA). cfDNA is continuously shed by healthy and tumor cells into the bloodstream and can reflect the entire tumor genome. Methylated Septin 9 (mSEPT9) DNA is the only FDA-approved methylated biomarker for the screening of CRC through the detection of cfDNA in the serum of CRC patients [30,31]. Warren et al. evaluated the FDA-approved mSEPT9 kit (Epigenomics AG, Germany) and reported an overall sensitivity and specificity in all CRC stages at $90 \%$ and $88 \%$, respectively. In early stages of cancer (I and II), the test was $87 \%$ sensitive. False-positive rate was reported at $12 \%$. mSEPT9 can be detected in precancerous lesions such as colorectal adenomas [18], but may not be reliably sensitive [32]. In a small prospective study, mSEPT9 was detected in 12\% of adenomas with a false-positive rate of 3\% [18]. From the year 2012 onwards, more studies were pointing toward the reliability of detecting mSEPT9 for CRC screening, with sensitivities ranging from 73\% to 95.6\% [33-37]. The heterogeneity of the sensitivities is likely affected by non-neoplastic factors including, but not limited to, demographics, methodology, lifestyle, and sex [37]. Asides from CRC, SEPT9 may also be involved in the tumor progression of leukemia [38], breast [39], ovarian [40], urologic [41], and brain cancers [42]. Nevertheless, the detection of mSEPT9 as cfDNA for CRC has been proven to be effective and should be considered to be included as a routine screening test for CRC.

The role of mSEPT9 in the screening of CRC is well established, but its prognostic role remains unclear. A recent study by Ma and co-workers linked higher levels of mSEPT9 in post-surgery CRC patients to higher cancer recurrence [43]. If validated by future studies, the same FDA-approved kit can be conveniently used in both screening and prognostic tests without extensive optimizations. Similar to mSEPT9, hypermethylations of other DNA biomarkers are also being investigated for their potential role in CRC screening [44]. Methylated DNA are ideal biomarkers for screening as epigenetic alterations occur very early in polyp-to-cancer progression [45]. In addition, there is a plethora of other potential CRC biomarkers in the form of cfDNA that are being studied [46], but will not be reviewed due to space constraints.

\subsection{Microsatellite Instability (MSI)}

Microsatellite instability (MSI) is described as having genes with altered lengths due to small insertions and deletions of short, repetitive DNA sequences throughout the genome [47,48]. These mutations are normally found in the coding single nucleotide repeats of tumor suppressor genes such as activin receptor type 2 and transforming growth factor $\beta$ R2 [49]. Approximately 15\% of all CRC cases are MSI, and patients with MSI-high (MSI-H) have a better prognosis in terms of longer overall survival (OS) and lower metastatic rate, but the tumors are more resistant to adjuvant chemotherapy such as 5-fluorouracil (5-FU) [50]. While MSI-H patients have been shown to be unresponsive to 5-FU, a meta-analysis by Jover et al. found that DNA mismatch repair (MMR) mutational status should not be indicative of chemotherapy efficacy [51]. MSI status by itself is also predictive for treatment response to the anti-programmed cell death 1 (PD-1) checkpoint inhibitor pembrolizumab in metastatic CRC (mCRC) patients. Pembrolizumab is only effective in mCRC patients with MSI-H status [52,53]. The exact interactions and mechanisms between checkpoint inhibitors and MSI status are currently unknown, but its approval by the FDA for the treatment of MSI-H solid tumors is based on several successes in clinical trials, as summarized by Marcus et al. The approval of pembrolizumab marks the 
first time in history a drug was approved solely based on a common molecular marker instead of the primary site of origin [7]. Recently, however, tumor mutational burden (TMB) is seen as a superior predictive marker over MSI status. TMB is measured in number of mutations/megabase (mut/MB). This was shown in a study by which anti-PD-1 immunotherapy was effective in microsatellite stable (MSS) CRC tumors with high TMB ( $\geq 10$ mut/MB) [54]. Contrary to other studies demonstrating the lack of efficacy of anti-PD-1 therapy in MSS patients, the importance of TMB over MSI status needs to be investigated further.

\subsection{KRAS (Kirsten Rat Sarcoma Viral Oncogene Homolog)}

The significance of (KRAS) Kirsten rat sarcoma viral oncogene homolog mutational profile as a negative predictive biomarker in the treatment response of mCRC using monoclonal antibody (mAb) against epidermal growth factor receptor (EGFR) is well established [55-57]. Clinical trials such as PRIME (panitumumab) and CRYSTAL (cetuximab) demonstrated positive response towards anti-EGFR $\mathrm{mAb}$ therapies only in wild-type (WT) KRAS mCRC patients. This is because KRAS activation in KRAS-mutated mCRC patients is independent of upstream EGFR activation [58,59]. A subsequent retrospective study by the FDA on seven randomized trials resulted in the approval of cetuximab and panitumumab only in WT KRAS mCRC patients [3,10]. Previously, KRAS mutation was identified only by mutations in Codon 12 and 13 of Exon 2, which was subsequently found to be insufficient for an accurate prediction of treatment response [60]. Thus, the CRC clinical guideline urges for extended $R A S$ mutation testing including KRAS and (NRAS) neuroblastoma RAS viral oncogene homolog in exon 2 (codons 12 and 13), exon 3 (codon 59 and 61), and exon 4 (codon 117 and 146) [19].

\subsection{BRAF (v-raf Murine Sarcoma Viral Oncogene Homolog B1)}

BRAF (v-raf murine sarcoma viral oncogene homolog B1) mutation occurs in $10 \%$ of CRC cases, with most of the mutations being presented in Codon 600 [61]. Recent evidences suggest that $B R A F$ mutation is a better predictor for the determination of anti-EGFR therapy responses than $R A S$ status. This is exemplified by the lower overall response rate (ORR) of anti-EGFR mAb in mutant $B R A F$ compared with mutant Exon 2 KRAS [62]. Additionally, BRAF mutation is associated with the promoter methylation of an MMR gene, MLH1 (human mutL homolog 1), where a positive BRAF mutation is normally accompanied with negative MMR mutation status. The negative mutation status of MMR is important for the prediction of MSI status $[63,64]$. In essence, patients with BRAF mutations are normally MSS, and are thus less likely to benefit from pembrolizumab treatment. BRAF mutation may also indicate poor prognosis in CRC patients [65], but is only demonstrated in $B R A F$-mutated patients with MSS status, as reported by Roth et al. The study showed that BRAF mutations hold no prognostic significance in patients with MSI-H [66]. In contrast, a recent meta-analysis of 1164 nonmetastatic CRC patients with MSI-H showed that BRAFV600E mutation does indicate poor prognosis in terms of OS [67]. Whilst the mutational testing of $B R A F$ is recommended in the CRC clinical guidelines for prognostic stratification, and MMR status identification, findings suggest that BRAF mutation alone is insufficient for a full diagnosis of CRC [19].

\subsection{Other Potential Biomarkers}

The complex genetic nature and heterogeneity of CRC necessitate the detection of a combination of biomarkers for a more accurate diagnosis. Thus, efforts are continuously made to validate additional CRC biomarkers. The sub-sections below will review CRC biomarkers that may potentially be incorporated into routine clinical diagnostics.

\subsubsection{Programmed Death-Ligand 1 (PD-L1)}

Programmed Death-Ligand 1 (PD-L1) expression is potentially predictive for the treatment response of pembrolizumab since high PD-L1 expression has been associated with MSI-H status [68,69]. The association between high PD-L1 expression and MSI-H status has, however, been contrasted in 
another study involving a larger cohort of almost 1,500 samples [70]. It is speculated that these large variations could be attributed to the difference in immunohistochemistry staining methods and scoring criteria due to the spatial and temporal heterogeneity of PD-L1 expression in mCRC patients [71]. Another study concluded that the effectiveness of the checkpoint inhibitor appears to be independent of PD-L1 expression level by tumor cells [72]. Collectively, it is evident that these limitations will need to be addressed before any clinical applications involving PD-L1 expression can be applied on CRC patients.

\subsubsection{Phosphatidylinositol-4,5-bisphosphate 3-kinase, Catalytic Subunit Alpha (PIK3CA)}

PIK3CA mutation has been studied for CRC treatment [73]. It is indicated that the PIK3CA exon 20 mutation confers resistance against anti-EGFR mAb therapy in CRC patients. The response rate (RR) was reported to be as low as $0 \%$, together with shorter progression-free survival (PFS) [74]. Conversely, another study demonstrated that PIK3CA did not significantly affect resistance against cetuximab [75]. An independent lab-developed test detecting H1047R and E545K mutations showed sensitivities of 5\% and $10 \%$ mutant allele fractions, respectively [76].

\subsubsection{Phosphatase and Tensin Homolog (PTEN)}

Another biomarker proposed to have predictive and prognostic potential in CRC treatment is Phosphatase and Tensin Homolog (PTEN) [77]. A study with 67 CRC patients demonstrated that $100 \%$ of the patients with negative expression of PTEN exhibited disease progression following treatment with cetuximab, whereas 30\% of the PTEN expression patients showed reduced disease progression [78]. Nevertheless, a study of a larger cohort found that it was not associated to the RR [79]. Another study showed that the negative expression of PTEN only negatively correlates to cetuximab response in tumor metastases but not primary tumor of CRC [80]. Interestingly, some studies showed promising results where PTEN gene alterations resulted in largely poor OS [81,82], while other findings showed no correlation between patients' survival with changes in PTEN expression [83,84]. Together, the credibility of PTEN as a potential predictive and prognostic marker cannot be determined as of current, and further investigations need to be carried out.

\subsubsection{Human Epidermal Growth Factor Receptor 2 (HER2)}

Human Epidermal Growth Factor Receptor 2 (HER2) is a proto-oncogene in the EGFR family that is mostly known for its oncogenic role in breast cancer [85]. In rare cases, HER2 is amplified in approximately $5 \%$ of $\mathrm{mCRC}$ patients with WT KRAS exon 2 . This gene exhibits a high concordance rate in both primary and metastatic tumors of CRC [86] and is mutually exclusive with mutations to NRAS, KRAS, and BRAF [87]. The amplification of HER2 in relation to anti-HER2 treatment response in $\mathrm{mCRC}$ patients was evaluated by the phase II HERACLES trial combining two anti-HER2 drugs, trastuzumab and lapatinib. The results of the trial suggested that HER2 amplification may have a potential role as a clinical predictive marker for $\mathrm{CRC}$, but the extreme rarity of this genetic alteration proves challenging for the validation of these results in a phase III clinical trial [88].

\subsubsection{Micro-RNA (miRNA)}

MiRNAs as biomarkers have received increasing attention recently for their predictive, diagnostic, and prognostic roles in CRC [89]. There are several miRNAs that are of importance to CRC. MiR-135a and miR-135b, for example, contribute to the regulation of the Wnt/Wingless pathway through the downregulation of APC (Adenomatous polyposis coli) gene [90] and can potentially act as prognostic markers [91,92]. Additionally, miR-17-3p and miR-92a (pooled sensitivity, 76\%, specificity, 64\%) can upregulate the cell proliferation of colon cancer cells and have been found to be elevated in the plasma and CRC tissues [93-95]. MiR-211, on the other hand, can act as a marker for both the diagnosis and prognosis of CRC [96], while miR-133a can be potentially used in predicting response to EGFR inhibitors [97]. 


\subsubsection{Consensus Molecular Subtypes (CMS)}

Recently, the possibility for the consensus molecular subtypes (CMS) of CRC to be used as biomarkers was explored. The subtypes are grouped into four based on the tumor gene expression pattern and are described as: (1) CMS1—strong immune activation, hypermutated, and MSI-H; (2) CMS2 - epithelial and canonical with marked WNT and MYC signaling; (3) CMS3 - epithelial with evident metabolic dysregulation; and (4) CMS4-mesenchymal with stromal invasion, angiogenesis and prominent transforming growth factor $\beta$ activation $[98,99]$. Prognostic and predictive values of CMS in mCRC patients independent of cancer staging were evaluated in multiple retrospective analysis. Collectively, CMS was shown to be significantly associated to lower OS and PFS. In terms of OS, CMS1 was associated to worst outcome in contrast to CMS2. Notably, positive drug response to bevacizumab and cetuximab was demonstrated specifically in CMS1 and CMS4, respectively. [100-103]. Significant correlations with known CRC biomarkers such as MSI-H, KRAS, and BRAF mutations were also reported [100]. A simplified summary of the biomarkers reviewed in Sections 2.1-2.4 is presented in Figure $2[18,19,43,54,56,57,70,74,78,79,88,91-94,96,97,100-105]$.

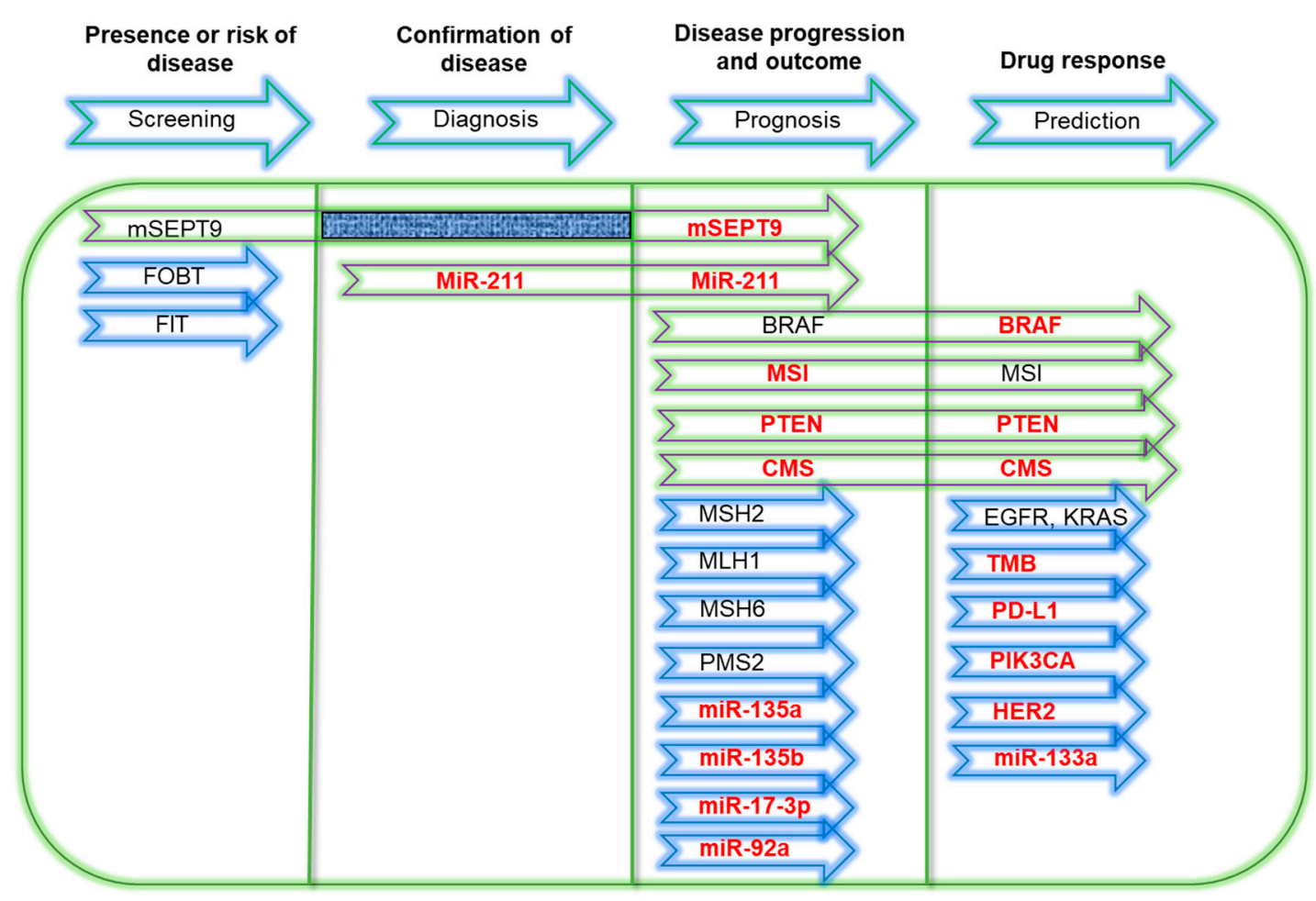

Figure 2. Simplified summary of CRC biomarkers. Green arrows represent biomarkers that have more than one role. Biomarkers colored in red are potential CRC biomarkers that require additional validations. BRAF- v-raf murine sarcoma viral oncogene homolog B1; FIT- fecal immunochemical test; CMS- consensus molecular subtypes; EGFR- epidermal growth factor receptor; FOBT- fecal occult blood test; HER2- human epidermal growth factor receptor 2; KRAS- Kirsten rat sarcoma viral oncogene homolog; miR- microRNA; MLH1- human mutL homolog 1; mSEPT9- methylated Septin 9; MSH2- human mutS homolog 2; MSI- Microsatellite instability; PD-L1- Programmed death-ligand 1; PIK3CA- phosphatidylinositol-4,5-bisphosphate 3-kinase, catalytic subunit alpha; PMS2- PMS1 homolog 2, mismatch repair system component; PTEN- Phosphatase and tensin homolog; TMB- tumor mutational burden.

\section{Current Molecular Diagnostic Technologies}

With advancements in technology, major progress has been made in understanding how variations in the genetic alterations of CRC can contribute toward clinical management. These advances have 
led to the development of precision medicine, which offers individualized medical care based on the patient's personal information and unique genetic profile. This concept has been proven to be successful in improving clinical outcomes compared with the relatively conventional method of indiscriminate radio/chemotherapy [106]. In fact, the list of drugs targeting specific genetic alterations approved by the FDA is rapidly growing for the treatment of advanced-stage solid tumors. Hence, it is important to understand and appreciate current and developing molecular methods available to diagnose CRC and the variety of molecular technologies available to map out the individual's unique molecular profile for efficient treatment strategies.

Before polymerase chain reaction (PCR) was invented, the detection of nucleic acid biomarkers was challenging due to scarcity of nucleic acid and tissue heterogeneity in samples. Now, tumor-specific DNA can be amplified to detectable levels through the more sensitive quantitative PCR (qPCR) [107], while RNA-based biomarkers such as miRNA can be detected using quantitative reverse transcription PCR (RT-qPCR) [94]. As technology improves, extremely scarce biomarkers such as tumor-specific cfDNA can be detected using PPCR, digital PCR, and NGS. Digital PCR is the latest variation of PCR that has since entered the diagnostic market recently, when detection of very rare events or gene variants in patient sample is challenging using qPCR. NGS, on the other hand, refers to high-throughput nucleic acid sequencing platforms using fragmented and PCR-amplified DNA, with performance comparable to digital PCR in terms of rare event detection [108]. The sub-sections below will discuss updates on the use of current molecular diagnostic technologies to detect major CRC-related biomarkers such as KRAS, BRAF, MSI, and so on.

\subsection{Detection of KRAS and BRAF Mutations}

For CRC, the mutational status of the genes $K R A S$ and $B R A F$ receives additional attention as they can negatively affect the patient's response towards anti-EGFR therapies, with the prevalence of somatic KRAS mutations being 40\% [109]. A myriad of molecular assays can detect these mutations with limit of detections ranging from 10-20\% mutant allele for Sanger sequencing [110], around 5\% for pyrosequencing $[110,111]$ and high-resolution melt (HRM) curve analysis [110,112], to 1-5\% for qPCR assays $[113,114]$. While direct sequencing remains the gold standard for KRAS and BRAF mutations detection, the method is not popular as it is laborious and lacks sensitivity [106,115].

\subsubsection{PCR-Based Detection}

Currently, there are several FDA-approved assays for the detection of KRAS and BRAF mutations, including cobas 4800 BRAF V600 mutation assay [116], cobas 4800 KRAS mutation assay, and therascreen KRAS assay [117,118]. These assays are FDA-approved for specific samples, but they are not suitable for use in specimens containing limited tissue such as fine needle aspiration and core biopsy [106]. A study by Nordgård et al. compared the performance and cost-effectiveness of two relatively new sensitive molecular methods for the detection of KRAS mutations called amplification refractory mutation system (ARMS) PCR assay and peptic nucleic acid (PNA) clamp PCR [119]. The ARMS PCR assay is an allele-specific PCR that detects a specific known mutated form of a gene [47], while the PNA clamp PCR is capable of selective amplification of nucleic acid sequences that differ by a single base [120]. In comparison, the PNA clamping assay was in favor as it is approximately 20 times cheaper than ARMS and demonstrated higher sensitivity levels [119]. Another method that utilizes a modified PCR protocol termed as coamplification at lower denaturation temperature PCR (COLD-PCR) was designed to detect KRAS and BRAF V600E mutations in combination with HRM. Compared with traditional PCR and direct sequencing that picked up 57 KRAS/BRAF mutations out of 117 CRC samples, this method detected $72 \mathrm{KRAS/BRAF}$ mutations, which translates to a $26.3 \%$ increase in detection. In addition, this method does not require time-consuming procedures and expensive equipment. Thus, it can be considered for diagnostic uses [121].

In respect of technology, many of the available routine molecular tests are heading toward automation, including EGFR mutation detection. The Idylla (Biocartis, Belgium) is a CE-IVD (CE 
Marking In Vitro Diagnostic for Medical Devices) marked fully-automated qPCR diagnostic platform for EGFR mutations that is simple to perform (hands-on time of less than $2 \mathrm{~min}$ ), does not require molecular expertise to run, is reliable, rapid, and has a small footprint [122]. Its KRAS mutation test allows the simultaneous detection of 21 mutations in clinically relevant codons $(12,13,59,61,117$, and 146) from FFPE (formalin-fixed paraffin-embedded) tissue samples, while its NRAS-BRAF mutation test can detect codons 12,13,59, 61, and 117 for NRAS and V600 mutations for BRAF [123]. Its ease of use, lack of expertise required to operate the system, and rapid turn-around time allows for the system to be placed in most clinical settings.

\subsubsection{Nucleic Acid Hybridization Assay}

There are cost-effective alternatives for the detection of KRAS and BRAF other than qPCR. This includes single nucleotide primer extension (SNaPshot) assay and reverse hybridization StripAssay. The SNaPshot is a flexible lab-developed test, while the StripAssay is a commercially available test $[115,124,125]$. For $K R A S$, the detection limits when compared with direct sequencing are $10 \%$ and $1 \%$, respectively [115]. In terms of sensitivity and turn-around time, the KRAS StripAssay is more favorable as it is a rapid and sensitive test that can be utilized when few tumor cells are present. For $B R A F$, Magnin et al. demonstrated similar results among SNaPshot, direct sequencing, and HRM [125]. Evaluation data on the performance of $B R A F$ using the StripAssay is, however, lacking and warrants further investigation. In short, SNaPshot and the KRAS StripAssay are suitable for laboratories lacking dedicated equipment, but Sarasqueta et al. has warned for KRAS-mutant to be confirmed to reduce the risk of false positives [115].

\subsubsection{Pre-PCR Isolation of Circulating Tumor Cells (CTCs)}

Since it is difficult to obtain sufficient or appropriate tumor samples for KRAS genotyping, an alternative method is required. Thus, circulating tumor cells (CTCs) have garnered a strong reaction from researchers and clinicians as they are thought to represent the tumor in real-time. The extremely low levels of DNA in CTCs can be detected through qPCR with HRM or droplet digital PCR (ddPCR). When compared, ddPCR was able to detect less than one KRAS mutant cell per $\mathrm{mL}$ of neat blood $(0.05 \%$ mutant ratio) while qPCR (TaqMeltPCR) and HRM could only detect up to $0.5 \%$ mutant ratio. In addition to its high sensitivity, the noninvasive nature of this procedure also allows for future opportunities to screen, diagnose, and monitor treatment or relapse in real-time without much discomfort to the patients [126]. One of the biggest hurdles to downstream analysis of CTCs is the effective and reliable method of isolating CTCs. There are several commercially available equipment for the isolation of CTCs through physical and biochemical properties such as size exclusion, deformability, and surface marker expression, but they are not without challenges. The size, rigidity, and surface marker expression pattern of CTCs are known to be highly variable. Furthermore, marker-based isolation of CTCs is only possible on the availability of the particular antibody [127].

\subsubsection{Circulating Free DNA (cfDNA) Detection}

Moving forward, RAS mutations can now be detected as cfDNA without the need to isolate CTCs. In a study published in 2018, researchers compared three diagnostic platforms for RAS mutations detection through cfDNA: ddPCR (Bio-Rad), NGS (Illumina), and BEAMing/OncoBEAM-RAS-CRC (BEAM, Sysmex Inostics). Tissue biopsies and time-matched blood samples were collected for the simultaneous comparison of mutation profiles between cfDNA and FFPE. The digital PCR-based BEAM reached a detection threshold of $0.03 \%$, significantly lower than the detection thresholds of the two compared platforms at $0.5-1 \%$. The superior sensitivity of the BEAM allowed the detection of KRAS mutations in 5/19 FFPE profiles shown to be negative. Based on the comparison of sensitivity, specificity, positive predictive value (PPV), and negative predictive value (NPV) among the three platforms (Table 1) [108], the BEAM is superior in most aspects, except for the specificity, which is slightly lower than that of the other two platforms. While the NGS is more suitable for the detection 
of a large coverage of mutations, the results are oftentimes confirmed with ddPCR [108]. In clinical settings where there is a need to balance the coverage of large mutation profiles with specificity of a particular mutation, it will be useful to have the BEAM together with the NGS as a complementary platform. As shown in Table 1, NGS may be a better choice, but the decision on which platform to select will require the consideration of footprint, cost, and turn-around-time (TAT). Furthermore, the clinical relevance of detecting mutations at very low allelic frequency was not assessed. While the results of ddPCR are less informative, it has the shortest TAT of only $8 \mathrm{~h}$ for the complete mutational analysis of KRAS exon 2. The more extensive mutational analysis of KRAS from BEAM and NGS will require around 2 days and 7 days, respectively. In terms of costing, NGS and the BEAM are comparable but cost twice as much compared with the ddPCR [108].

Table 1. Comparison of the sensitivity, specificity, PPV (positive predictive value), and NPV (negative predictive value) of ddPCR, BEAM, and NGS for KRAS detection [108].

\begin{tabular}{ccccc}
\hline Platform & Sensitivity (\%) & Specificity & PPV (\%) & NPV (\%) \\
\hline ddPCR & 47 & 77 & 70 & 55 \\
BEAM & 93 & 69 & 78 & 90 \\
NGS & 73 & 77 & 79 & 71 \\
\hline
\end{tabular}

\subsection{Detection of Microsatellite Instability (MSI)/Microsatellite Stable (MSS) Status}

Similar to the detection of other biomarkers, MSI can be detected through PCR-based methods and NGS. The versatility of NGS allows for the simultaneous detection of thousands of different microsatellite loci with a limit of detection of 1\% MSI in MSS background. However, the use of NGS for MSI detection is uncommon, as data interpretation requires specific algorithms and computational methods [128]. Notably, MSI can also be detected indirectly through the detection of miRNA biomarkers.

There are several methods in which MSI can be detected. Capillary electrophoresis fragment analysis is one of the earliest molecular method using PCR-amplified samples, but presents with a low limit of detection of $1 \%$ to $10 \%$ [128]. This method usually interrogates epiphenomenon related to MSI, such as MMR gene loci [129]. The 1997 National Cancer Institute-sponsored MSI workshop recommends the interrogation of five microsatellite loci; three dinucleotide (D2S123, D5S346, and D17S250) and two mononucleotide repeats (BAT-25, BAT-26), which led to the development of the Bethesda panel. This assay amplifies the repeats through a single multiplex PCR reaction, followed by analysis using capillary electrophoresis. MSI-H is reported when two or more loci are instable, while instability at a single locus or no instability will be reported as MSI-low and MSS, respectively. Commercially, Promega Corp developed the MSI Analysis System version 1.1 that detects five mononucleotide (BAT-25, BAT-26, NR-21, NR-24, and MONO-27) and two pentanucleotide repeats (PentaC and PentaD). Like the previous assay, capillary electrophoresis is subsequently used for analysis. MSI-H is reported when two or more mononucleotide loci are instable, while instability at a single mononucleotide locus represents MSI-low, and no instability represents MSS. Murphy et al. compared the two assays with 34 CRC patient samples and found that the concordance rate was at $85 \%$. MSI-H and MSS cases were fully concordant on both assays. While both assays performed adequately in detecting MSI cases, the authors concluded that the MSI Analysis System was superior and will be a better option to resolve cases of MSI-low into either MSS or MSI-H [130]. In another study, the Promega MSI Analysis System version 1.2 was compared to a new "one mononucleotide" MSI marker test, which detects T25 mononucleotide repeat of the caspase 2 gene (CAT25). The CAT25 MSI test claims to be a simplified assay with reduced cost and may improve efficiency. Based on the results, the authors concluded that the CAT25 assay performed equally well to the commercial kit and should be considered as a replacement to a five markers test, or at least, be included in the MSI detection panel [131]. Additionally, an MSI gene expression assay with 64 genes has been made available as a diagnostic assay, which helps to accurately identify MSI-positive and MSI-like patients that are not 
easily recognized by IHC or PCR. Furthermore, this assay does not require a reference paracancerous tissue from the patient for comparison [65].

\section{3. miRNA Detection}

MSI status can also be tested through the detection of miRNA biomarkers in the plasma as cell-free form. One of the methods is through RT-qPCR, which measures the quantity of miRNA indirectly in real-time [132]. Microarray, which utilizes in situ hybridization of predesigned probes to the target miRNA is also a reliable method to quantify the amount of miRNA in the sample [133]. An MSI oligonucleotide microarray diagnostic assay based on spotted locked nucleic acid (LNA) can be used to profile the expression of up to 315 miRNAs [89]. While RT-PCR and microarray are highly sensitive and specific, the operational cost is expensive. Dedicated equipment, facilities, and trained personnel are also required to run these tests $[134,135]$. Thus, these methods may not be suitable for clinics or settings with poor resources.

Alternatively, resource-lacking clinical settings may opt for lateral flow nucleic acid strip assay using gold nanoparticles [135]. This assay has been demonstrated to be more apt as a point-of-care test as it is sensitive, inexpensive, rapid, and simple to use $[135,136]$. Similar to the microarray system, this assay utilizes predesigned probes conjugated to gold nanoparticles targeting specific miRNAs, leading to the formation of visible bands on the strip [47]. The results are semiquantitative as the intensity of the band increases with the quantity of the miRNA, but can be made more quantitative with the use of a quantitative detection platform $[135,136]$. It was shown that miRNAs can be quantified to as low as $1 \mathrm{fmol}$, and with the use of silver enhancement, it can be as low as 5 amol [134].

\subsection{Detection of Other Biomarkers}

In theory, most of the molecular biomarkers discussed other than $K R A S, B R A F$, and MSI can be detected using similar diagnostic platforms such as qPCR and NGS. This is shown in several studies attempting to validate the use of additional biomarkers for CRC diagnostics. A brief summary of CRC biomarkers and their respective diagnostic platforms from Section 2 and 3 is tabulated in Table 2.

Table 2. Summary of CRC biomarkers and their respective diagnostic platforms reviewed.

\begin{tabular}{|c|c|c|}
\hline Biomarker & Diagnostic Platform & References \\
\hline mSEPT9 & - Methylation-specific real-time PCR & [18] \\
\hline \multirow{5}{*}{ MSI } & - Immunohistochemistry & [64] \\
\hline & - Next-generation sequencing (NGS) & [89] \\
\hline & - Fragment analysis & [128] \\
\hline & - Gene expression assay & [130] \\
\hline & - miRNA microarray & [89] \\
\hline TMB & - Whole exome sequencing & [54] \\
\hline \multirow{11}{*}{ KRAS } & $\begin{array}{l}\text { - qPCR (Roche Cobas } 4800 \text { KRAS mutation, Qiagen therascreen KRAS, } \\
\text { Biocartis KRAS mutation assay) }\end{array}$ & {$[117,122]$} \\
\hline & - Direct sequencing & [106] \\
\hline & - Pyrosequencing & [111] \\
\hline & - Next-generation sequencing (NGS) & [108] \\
\hline & - High-resolution melt curve (HRM) & [110] \\
\hline & - Amplification refractory mutation system (ARMS) PCR & [119] \\
\hline & - Peptic nucleic acid (PNA) clamp PCR & [119] \\
\hline & - COLD-PCR & [121] \\
\hline & - Single nucleotide primer extension (SNaPshot) & [115] \\
\hline & - Reverse hybridization KRAS StripAssay & [115] \\
\hline & - Digital PCR (Bio-Rad droplet digital PCR, Sysmex BEAMing) & [108] \\
\hline
\end{tabular}


Table 2. Cont.

\begin{tabular}{|c|c|c|}
\hline$\overline{\text { Biomarker }}$ & Diagnostic Platform & $\overline{\text { References }}$ \\
\hline$B R A F$ & $\begin{array}{l}\text { - } \text { qPCR (Roche Cobas } 4800 \text { BRAF V600, Biocartis Idylla NRAS-BRAF } \\
\text { mutation assay) } \\
\text { - Direct sequencing } \\
\text { - Pyrosequencing } \\
\text { - Next-generation sequencing (NGS) } \\
\text { - High-resolution melt curve (HRM) } \\
\text { - COLD-PCR } \\
\text { - Immunohistochemistry } \\
\text { - Single nucleotide primer extension (SNaPshot) }\end{array}$ & $\begin{array}{c}{[117,122]} \\
{[106]} \\
{[111]} \\
{[108]} \\
{[110]} \\
{[121]} \\
{[106]} \\
{[125]} \\
{[124]}\end{array}$ \\
\hline miRNA & $\begin{array}{l}\text { - Microarray—spotted locked nucleic acid (LNA) } \\
\text { - } \text { RT-qPCR } \\
\text { - Lateral flow nucleic acid strip assay using gold nanoparticles }\end{array}$ & $\begin{array}{c}{[89]} \\
{[132]} \\
{[47]}\end{array}$ \\
\hline PD-L1 & - Immunohistochemistry & [68] \\
\hline PIK3CA & $\begin{array}{l}\text { - Real-time PCR } \\
\text { - Immunohistochemistry } \\
\text { - Gene sequencing }\end{array}$ & $\begin{array}{l}{[76]} \\
{[73]} \\
{[73]}\end{array}$ \\
\hline HER2 & $\begin{array}{l}\text { - Immunohistochemistry } \\
\text { - Quantitative reverse transcription PCR (RT-qPCR) }\end{array}$ & $\begin{array}{l}{[86]} \\
{[85]}\end{array}$ \\
\hline PTEN & $\begin{array}{l}\text { - Indirect immunofluorescence } \\
\text { - Immunohistochemistry }\end{array}$ & $\begin{array}{l}{[78]} \\
{[77]}\end{array}$ \\
\hline CMS & - Gene expression microarray & [99] \\
\hline
\end{tabular}

\section{Challenges and Limitations}

\subsection{Choice of Molecular Platform}

For cancer diagnosis and screening, accuracy, specificity, and fast TAT should be given critical attention [137]. qPCR is currently the choice of molecular method for biomarker detection as many tests are validated and it is more readily available than digital PCR and NGS. In addition, test results can be available within a day. However, the throughput is limited to several targets, and prior knowledge of the target DNA is required. Conversely, a single run of NGS is capable of providing invaluable information including mutations, chromosomal rearrangements, and copy number alterations without any prior knowledge of the targets [138], although it may take up to 7 days for results to be available [108]. Superior sensitivity, specificity, and throughput must not be the sole reason for the molecular platform chosen. Instead, consideration must be given to the type of clinical application, cost effectiveness, and the necessity for superior performance, as it is not possible for all medical settings to incorporate advanced molecular laboratories. A centralized and highly specialized cancer diagnostic lab will need to be established in major cities or states to process samples from surrounding clinical settings, but may have several drawbacks. The need to handle sensitive clinical samples during transportation and process samples in batches will lead to a longer TAT. Consequently, some critically ill patients may have to wait for several days or up to weeks before receiving appropriate treatment $[19,139]$.

\subsection{Laboratory Operations}

Guidelines for CRC molecular testing have been established in a joint effort by the American Society for Clinical Pathology (ASCP), American Society of Clinical Oncology (ASCO), Association for Molecular Pathology (AMP), and the College of American Pathologists (CAP). For clinical sample management and laboratory operations, the recommendations by the guidelines will be summarized and discussed here. Firstly, policies should be established in all laboratories to ensure efficient allocation of tissue for molecular tests, especially in scarce specimens. Pathologists can contribute to this by 
evaluating tissue quantity, quality, and malignant tumor cell fraction. Another way is to limit the number of tissue fragments per individual cassette. Prior assessment of the patients' previous CRC status will contribute to unnecessary repeat tests. The usage of appropriate tissue type may also aid in limiting the wastage of precious tissue; the guidelines recommend using recurrent or mCRC tissues for predictive biomarker testing involved in cancer treatment given that samples are available and adequate, followed by primary tumor tissue. For molecular biomarker mutational testing, FFPE tissue samples are considered acceptable. However, an alteration to the tissue processing protocols or the use of other specimens (including samples of cytologic origins) necessitates additional validation [19].

Another recommended practice to consider is to provide clinically appropriate turn-around time (TAT), which will contribute to the alleviation of patient anxiety and the execution of timely patient management decisions. This can be achieved through the optimal utilization of relevant molecular and IHC tests, possibly through multiplexed assays. In general, nonacute biomarker test results should be available within 10 days of test ordering $[19,140]$. The 10 day timeframe should include the time taken for test orders to reach the laboratory, tissue block retrieval, and shipment of said blocks to the performing laboratory. Every effort should be taken by the laboratory to minimize delays in tissue block retrieval, processing time, and the availability of results [19].

\section{Conclusions and Future Perspectives}

It is important to understand the epidemiology, etiology, mechanisms, and how to improve diagnostics and treatment in CRC. Owing to the continuous research of CRC by dedicated researchers, the mechanisms underlying CRC are now more understood, resulting in extensive diagnostic and treatment options. Detection of circulating free DNA from liquid biopsy is currently in trend as it is less invasive and extremely sensitive. Notably, the detection of methylated SEPT9 in the plasma of CRC patients has been shown to be a reliable screening tool and has been FDA-approved as the first liquid biopsy screening tool for CRC. These sensitive diagnostic tools will shape how and what treatments are prescribed, as certain targeted treatments are only effective in certain genotypes of CRC. Evidently, there will be limitations to the implementation of such tests and treatments in all healthcare settings. Furthermore, as with all new technology, validation studies and standardization of operations and methodologies remain a challenge. In essence, CRC continues to be one of the most prevalent cancers in the world and is mostly detected in advanced stages. Thus, current and future research should strongly emphasize on early screening of CRC as it is one of the most effective way to prevent CRC. The future of CRC prevention, diagnostic, and treatment lies in the decentralization of molecular tests. Currently, extremely sensitive molecular methods for biomarker detection require sophisticated equipment, facilities, and trained personnel, resulting in the need for centralization and longer TAT. This necessitates the development of simple, automated, and robust biomarker detection platforms with smaller footprints.

Author Contributions: Conceptualization, S.-W.P. and S.-Y.T.; resources, S.A., W.W.-D.L., J.S.-H.L. and K.-B.P.; writing-original draft preparation, S-.W.P., S.-Y.T. and N.J.A.; writing-review and editing, S.-C.P. and S.-Y.T.; supervision, S.-Y.T.; funding acquisition, S.-Y.T., S.-C.P. and J.S.-H.L. All authors have read and agreed to the published version of the manuscript.

Funding: This research was partly funded by Sunway Internal Research Grant 2019 (grant number INT-2019-SHMS-DMS-01) and Sunway Medical Centre Research Funds (SRC/002/2017/FR and SRC/003/2017/FR).

Acknowledgments: Siew-Wai Pang and Noel Jacques Awi are recipients of Sunway University Postgraduate's Degree by Research Studentship.

Conflicts of Interest: The authors declare no conflict of interest. 


\section{Abbreviations}

\begin{tabular}{|c|c|}
\hline APC & Adenomatous polyposis coli \\
\hline ARMS & Amplification refractory mutation system \\
\hline$B R A F$ & B-Raf protein \\
\hline cfDNA & Circulating free DNA \\
\hline COLD-PCR & Coamplification at lower denaturation temperature PCR \\
\hline CRC & Colorectal cancer \\
\hline CTC & Circulating tumor cells \\
\hline ddPCR & Droplet digital PCR \\
\hline DNA & Deoxyribonucleic acid \\
\hline EGFR & Epidermal growth factor receptor \\
\hline FDA & Food and Drug Administration \\
\hline FFPE & Formalin-fixed paraffin embedded \\
\hline FIT & Fecal immunochemical test \\
\hline FOBT & Fecal occult blood test \\
\hline HER2 & Human epidermal growth factor 2 \\
\hline IHC & Immunohistochemistry \\
\hline KRAS & Kirten rat sarcoma viral oncogene homolog \\
\hline LNA & Locked nucleic acid \\
\hline $\mathrm{mAb}$ & monoclonal antibody \\
\hline $\mathrm{mCRC}$ & metastatic colorectal cancer \\
\hline miRNA & microRNA \\
\hline MMR & Mismatch repair \\
\hline MSI & Microsatellite instability \\
\hline NGS & Next-generation sequencing \\
\hline NRAS & Neuroblastoma RAS viral oncogene homolog \\
\hline ORR & Overall response rate \\
\hline OS & Overall survival \\
\hline PD-L1 & Programmed cell death protein ligand 1 \\
\hline PFS & Progression-free survival \\
\hline PNA & Peptide nucleic acid \\
\hline RR & Response rate \\
\hline RT-qPCR & Quantitative reverse transcription PCR \\
\hline SEPT9 & Septin 9 \\
\hline TKI & Tyrosine kinase inhibitor \\
\hline TMBWNT & Tumor mutational burdenWingless and int- 1 \\
\hline WT & Wild-type \\
\hline 5-FU & 5-fluorouracil \\
\hline
\end{tabular}

\section{References}

1. Bray, F.; Ferlay, J.; Soerjomataram, I.; Siegel, R.L.; Torre, L.A.; Jemal, A. Global cancer statistics 2018: GLOBOCAN estimates of incidence and mortality worldwide for 36 cancers in 185 countries. CA Cancer J. Clin. 2018, 68, 394-424. [CrossRef]

2. Heemskerk-Gerritsen, B.A.M.; Rookus, M.A.; Aalfs, C.M.; Ausems, M.G.E.M.; Collée, J.M.; Jansen, L.; Kets, C.M.; Keymeulen, K.B.M.I.; Koppert, L.B.; Meijers-Heijboer, H.E.J.; et al. Improved overall survival after contralateral risk-reducing mastectomy in brca1/2 mutation carriers with a history of unilateral breast cancer: A prospective analysis. Int. J. Cancer 2015, 136, 668-677. [CrossRef] [PubMed]

3. Hurwitz, H.; Fehrenbacher, L.; Novotny, W.; Cartwright, T.; Hainsworth, J.; Heim, W.; Berlin, J.; Baron, A.; Griffing, S.; Holmgren, E.; et al. Bevacizumab plus Irinotecan, Fluorouracil, and Leucovorin for metastatic colorectal cancer. N. Engl. J. Med. 2004, 350, 2335-2342. [CrossRef] [PubMed]

4. Kalyan, A.; Kircher, S.; Shah, H.; Mulcahy, M.; Benson, A. Updates on immunotherapy for colorectal cancer. J. Gastrointest. Oncol. 2018, 9, 160-169. [CrossRef] [PubMed] 
5. Kircher, S.M.; Nimeiri, H.S.; Benson, A.B. Targeting angiogenesis in colorectal cancer tyrosine kinase inhibitors. Cancer J. 2016, 22, 182-189. [CrossRef] [PubMed]

6. O'Neil, B.H.; Wallmark, J.M.; Lorente, D.; Elez, E.; Raimbourg, J.; Gomez-Roca, C.; Ejadi, S.; Piha-Paul, S.A.; Stein, M.N.; Abdul Razak, A.R.; et al. Safety and antitumor activity of the anti-PD-1 antibody pembrolizumab in patients with advanced colorectal carcinoma. PLoS ONE 2017, 12, e0189848. [CrossRef] [PubMed]

7. Marcus, L.; Lemery, S.J.; Keegan, P.; Pazdur, R. FDA approval summary: Pembrolizumab for the treatment of microsatellite instability-high solid tumors. Clin. Cancer Res. 2019, 25, 3753-3758. [CrossRef]

8. Lee, J.J.; Chu, E. The adjuvant treatment of stage III colon cancer: Might less be more? Oncology 2018, 32, 437-442.

9. FDA Approves Nivolumab Plus Ipilimumab Combination for Intermediate or Poor-Risk Advanced Renal Cell Carcinoma. Available online: https://www.fda.gov/Drugs/InformationOnDrugs/ApprovedDrugs/ucm604685. htm (accessed on 23 July 2019).

10. Rogers, J.E. Patient considerations in metastatic colorectal cancer-role of panitumumab. Onco Targets Ther. 2017, 10, 2033-2044. [CrossRef]

11. Jitawatanarat, P.; Ma, W.W. Update on antiangiogenic therapy in colorectal cancer: Aflibercept and regorafenib. J. Gastrointest. Oncol. 2013, 4, 231-238. [CrossRef]

12. Kurkjian, C.; Kummar, S. Advances in the treatment of metastatic colorectal cancer. Disease-a-Month 2010, 56, 187-203. [CrossRef] [PubMed]

13. Rothenberg, M.L. Irinotecan (CPT-11): Recent developments and future directions-colorectal cancer and beyond. Oncologist 2004, 6, 66-80. [CrossRef] [PubMed]

14. Ibrahim, A. FDA drug approval summaries: Oxaliplatin. Oncologist 2004, 9, 8-12. [CrossRef] [PubMed]

15. Bertino, J.R. Chemotherapy of colorectal cancer: History and new themes. Semin. Oncol. 1997, 24, S18-3-S18-7. [PubMed]

16. Milsom, J.W.; Hammerhofer, K.A. Role of laparoscopic techniques in colorectal cancer surgery. Oncology 1995, 9, 393-398.

17. Heald, R.J.; Husband, E.M.; Ryall, R.D.H. The mesorectum in rectal cancer surgery-The clue to pelvic recurrence? Br. J. Surg. 1982, 69, 613-616. [CrossRef]

18. Warren, J.D.; Xiong, W.; Bunker, A.M.; Vaughn, C.P.; Furtado, L.V.; Roberts, W.L.; Fang, J.C.; Samowitz, W.S.; Heichman, K.A. Septin 9 methylated DNA is a sensitive and specific blood test for colorectal cancer. BMC Med. 2011, 9, 133. [CrossRef]

19. Sepulveda, A.R.; Hamilton, S.R.; Allegra, C.J.; Grody, W.; Cushman-Vokoun, A.M.; Funkhouser, W.K.; Kopetz, S.E.; Lieu, C.; Lindor, N.M.; Minsky, B.D.; et al. Molecular biomarkers for the evaluation of colorectal cancer: Guideline from the American society for clinical pathology, college of American pathologists, association for molecular pathology, and American society of clinical oncology. Arch. Pathol. Lab. Med. 2017, 35, 1453-1486. [CrossRef]

20. Bordeaux, J.; Welsh, A.W.; Agarwal, S.; Killiam, E.; Baquero, M.T.; Hanna, J.A.; Anagnostou, V.K.; Rimm, D.L. Antibody validation. Biotechniques 2010, 48, 197-209. [CrossRef]

21. O’Hurley, G.; Sjöstedt, E.; Rahman, A.; Li, B.; Kampf, C.; Pontén, F.; Gallagher, W.M.; Lindskog, C. Garbage in, garbage out: A critical evaluation of strategies used for validation of immunohistochemical biomarkers. Mol. Oncol. 2014, 8, 783-798. [CrossRef]

22. Allott, E.H.; Geradts, J.; Sun, X.; Cohen, S.M.; Zirpoli, G.R.; Khoury, T.; Bshara, W.; Chen, M.; Sherman, M.E.; Palmer, J.R.; et al. Intratumoral heterogeneity as a source of discordance in breast cancer biomarker classification. Breast Cancer Res. 2016, 18, 68. [CrossRef] [PubMed]

23. Comănescu, M.; Arsene, D.; Ardeleanu, C.; Bussolati, G. The mandate for a proper preservation in histopathological tissues. Rom. J. Morphol. Embryol. 2012, 53, 233-242. [PubMed]

24. Laterza, O.F.; Hendrickson, R.C.; Wagner, J.A. Molecular biomarkers. Drug Inf. J. 2007, 41, 573-585. [CrossRef]

25. Pignone, M.; Saha, S.; Hoerger, T.; Mandelblatt, J. Cost-effectiveness analyses of colorectal cancer screening: A systematic review for the U.S. Preventive Services Task Force. Ann. Intern. Med. 2002, 137, 96-104. [CrossRef] [PubMed]

26. Vogelstein, B.; Fearon, E.R.; Hamilton, S.R.; Kern, S.E.; Preisinger, A.C.; Leppert, M.; Smits, A.M.M.; Bos, J.L. Genetic alterations during colorectal-tumor development. N. Engl. J. Med. 1988, 319, 525-532. [CrossRef] [PubMed]

27. Lieberman, D.A. Clinical practice. Screening for colorectal cancer. N. Engl. J. Med. 2009, 361, 1179-1187. [CrossRef] [PubMed] 
28. Gao, Y.; Wang, J.; Zhou, Y.; Sheng, S.; Qian, S.Y.; Huo, X. Evaluation of serum CEA, CA19-9, CA72-4, CA125 and Ferritin as diagnostic markers and factors of clinical parameters for colorectal cancer. Sci. Rep. 2018, 8, 2732. [CrossRef] [PubMed]

29. Shiratsuchi, I.; Akagi, Y.; Kawahara, A.; Kinugasa, T.; Romeo, K.; Yoshida, T.; Ryu, Y.; Gotanda, Y.; Kage, M.; Shirouzu, K. Expression of IGF-1 and IGF-1R and their relation to clinicopathological factors in colorectal cancer. Anticancer Res. 2011, 31, 2541-2545.

30. Tóth, K.; Wasserkort, R.; Sipos, F.; Kalmár, A.; Wichmann, B.; Leiszter, K.; Valcz, G.; Juhász, M.; Miheller, P.; Patai, Á.V.; et al. Detection of methylated Septin 9 in tissue and plasma of colorectal patients with neoplasia and the relationship to the amount of circulating cell-free DNA. PLoS One 2014, 9, e115415. [CrossRef]

31. Wang, J.Y.; Hsieh, J.S.; Chang, M.Y.; Huang, T.J.; Chen, F.M.; Cheng, T.L.; Alexandersen, K.; Huang, Y.S.; Tzou, W.S.; Lin, S.R. Molecular detection of APC, K-ras, and p53 mutations in the serum of colorectal cancer patients as circulating biomarkers. World J. Surg. 2004, 28, 721-726. [CrossRef]

32. Church, T.R.; Wandell, M.; Lofton-Day, C.; Mongin, S.J.; Burger, M.; Payne, S.R.; Castaños-Vélez, E.; Blumenstein, B.A.; Rösch, T.; Osborn, N.; et al. Prospective evaluation of methylated SEPT9 in plasma for detection of asymptomatic colorectal cancer. Gut 2014, 63, 317-325. [CrossRef] [PubMed]

33. Wu, D.; Zhou, G.; Jin, P.; Zhu, J.; Li, S.; Wu, Q.; Wang, G.; Sheng, J.; Wang, J.; Song, L.; et al. Detection of colorectal cancer using a simplified SEPT9 gene methylation assay is a reliable method for opportunistic screening. J. Mol. Diagn. 2016, 18, 535-545. [CrossRef] [PubMed]

34. Jin, P.; Kang, Q.; Wang, X.; Yang, L.; Yu, Y.; Li, N.; He, Y.Q.; Han, X.; Hang, J.; Zhang, J.; et al. Performance of a second-generation methylated SEPT9 test in detecting colorectal neoplasm. J. Gastroenterol. Hepatol. 2015, 30, 830-833. [CrossRef] [PubMed]

35. Su, X.L.; Wang, Y.F.; Li, S.J.; Zhang, F.; Cui, H.W. High methylation of the SEPT9 gene in Chinese colorectal cancer patients. Genet. Mol. Res. 2014, 13, 2513-2520. [CrossRef] [PubMed]

36. Tóth, K.; Sipos, F.; Kalmár, A.; Patai, Á.V.; Wichmann, B.; Stoehr, R.; Golcher, H.; Schellerer, V.; Tulassay, Z.; Molnár, B. Detection of methylated SEPT9 in plasma is a reliable screening method for both left- and right-sided colon cancers. PLoS One 2012, 7, e46000. [CrossRef]

37. Wang, Y.; Chen, P.-M.; Liu, R.-B. Advance in plasma SEPT9 gene methylation assay for colorectal cancer early detection. World J. Gastrointest. Oncol. 2018, 10, 15-22. [CrossRef]

38. Kojima, K.; Sakai, I.; Hasegawa, A.; Niiya, H.; Azuma, T.; Matsuo, Y.; Fujii, N.; Tanimoto, M.; Fujita, S. FLJ10849, a septin family gene, fuses MLL in a novel leukemia cell line CNLBC1 derived from chronic neutrophilic leukemia in transformation with $\mathrm{t}(4 ; 11)(\mathrm{q} 21 ; \mathrm{q} 23)$. Leukemia 2004, 18, 998-1005. [CrossRef]

39. Montagna, C.; Lyu, M.S.; Hunter, K.; Lukes, L.; Lowther, W.; Reppert, T.; Hissong, B.; Weaver, Z.; Ried, T. The Septin 9 (MSF) gene is amplified and overexpressed in mouse mammary gland adenocarcinomas and human breast cancer cell lines. Cancer Res. 2003, 63, 2179-2187.

40. Burrows, J.F.; Chanduloy, S.; McIlhatton, M.A.; Nagar, H.; Yeates, K.; Donaghy, P.; Price, J.; Godwin, A.K.; Johnston, P.G.; Russell, S.E.H. Altered expression of the septin gene, SEPT9, in ovarian neoplasia. J. Pathol. 2003, 201, 581-588. [CrossRef]

41. Amir, S.; Golan, M.; Mabjeesh, N.J. Targeted knockdown of SEPT9_v1 inhibits tumor growth and angiogenesis of human prostate cancer cells concomitant with disruption of hypoxia-inducible factor-1 pathway. Mol. Cancer Res. 2010, 8, 643-652. [CrossRef]

42. Kim, D.-S.; Hubbard, S.-L.; Peraud, A.; Salhia, B.; Sakai, K.; Rutka, J.T. Analysis of mammalian Septin expression in human malignant brain tumors. Neoplasia 2004, 6, 168-178. [CrossRef] [PubMed]

43. Ma, Z.Y.; Law, W.L.; Ng, E.K.O.; Chan, C.S.Y.; Lau, K.S.; Cheng, Y.Y.; Shin, V.Y.; Kwong, A.; Leung, W.K. Methylated Septin 9 and carcinoembryonic antigen for serological diagnosis and monitoring of patients with colorectal cancer after surgery. Sci. Rep. 2019, 9, 10326. [CrossRef] [PubMed]

44. Ma, Z.; Williams, M.; Cheng, Y.Y.; Leung, W.K. Roles of methylated DNA biomarkers in patients with colorectal cancer. Dis. Mark. 2019, 2019, 2673543. [CrossRef] [PubMed]

45. Nguyen, M.T.; Weinberg, D.S. Biomarkers in colorectal cancer screening. JNCCN J. Natl. Compr. Cancer Netw. 2016, 14, 1033-1040. [CrossRef] [PubMed]

46. Vymetalkova, V.; Cervena, K.; Bartu, L.; Vodicka, P. Circulating cell-free DNA and colorectal cancer: A systematic review. Int. J. Mol. Sci. 2018, 19, 3356. [CrossRef] [PubMed] 
47. Tsang, A.H.F.; Cheng, K.H.; Wong, A.S.P.; Ng, S.S.M.; Ma, B.B.Y.; Chan, C.M.L.; Tsui, N.B.Y.; Chan, L.W.C.; Yung, B.Y.M.; Wong, S.C.C. Current and future molecular diagnostics in colorectal cancer and colorectal adenoma. World J. Gastroenterol. 2014, 20, 3847-3857. [CrossRef]

48. Vilar, E.; Gruber, S.B. Microsatellite instability in colorectal cancer-the stable evidence. Nat. Rev. Clin. Oncol. 2010, 7, 153-162. [CrossRef]

49. Legolvan, M.P.; Taliano, R.J.; Resnick, M.B. Application of molecular techniques in the diagnosis, prognosis and management of patients with colorectal cancer: A practical approach. Hum. Pathol. 2012, 43, 1157-1168. [CrossRef]

50. Huth, L.; Jäkel, J.; Dahl, E. Molecular diagnostic applications in colorectal cancer. Microarrays 2014, 3, 168-179. [CrossRef]

51. Jover, R.; Zapater, P.; Castells, A.; Llor, X.; Andreu, M.; Cubiella, J.; Balaguer, F.; Sempere, L.; Xicola, R.M.; Bujanda, L.; et al. The efficacy of adjuvant chemotherapy with 5-fluorouracil in colorectal cancer depends on the mismatch repair status. Eur. J. Cancer 2009, 45, 365-373. [CrossRef]

52. Overman, M.J.; Lonardi, S.; Wong, K.Y.M.; Lenz, H.J.; Gelsomino, F.; Aglietta, M.; Morse, M.A.; Van Cutsem, E.; McDermott, R.; Hill, A.; et al. Durable clinical benefit with nivolumab plus ipilimumab in DNA mismatch repair-deficient/microsatellite instability-high metastatic colorectal cancer. J. Clin. Oncol. 2018, 36, 773-779. [CrossRef] [PubMed]

53. Overman, M.J.; McDermott, R.; Leach, J.L.; Lonardi, S.; Lenz, H.J.; Morse, M.A.; Desai, J.; Hill, A.; Axelson, M.; Moss, R.A.; et al. Nivolumab in patients with metastatic DNA mismatch repair-deficient or microsatellite instability-high colorectal cancer (CheckMate 142): An open-label, multicentre, phase 2 study. Lancet Oncol. 2017, 18, 1182-1191. [CrossRef]

54. Gong, J.; Wang, C.; Lee, P.P.; Chu, P.; Fakih, M. Response to PD-1 blockade in microsatellite stable metastatic colorectal cancer harboring a POLE mutation. JNCCN J. Natl. Compr. Cancer Netw. 2017, 15, 142-147. [CrossRef] [PubMed]

55. Sorich, M.J.; Wiese, M.D.; Rowland, A.; Kichenadasse, G.; McKinnon, R.A.; Karapetis, C.S. Extended RAS mutations and anti-EGFR monoclonal antibody survival benefit in metastatic colorectal cancer: A meta-analysis of randomized, controlled trials. Ann. Oncol. 2015, 26, 13-21. [CrossRef] [PubMed]

56. Van Cutsem, E.; Lenz, H.J.; Köhne, C.H.; Heinemann, V.; Tejpar, S.; Melezínek, I.; Beier, F.; Stroh, C.; Rougier, P.; Han Van Krieken, J.; et al. Fluorouracil, leucovorin, and irinotecan plus cetuximab treatment and RAS mutations in colorectal cancer. J. Clin. Oncol. 2015, 33, 692-700. [CrossRef] [PubMed]

57. Rodrigues, D.; Longatto-Filho, A.; Martins, S.F. Predictive biomarkers in colorectal cancer: From the single therapeutic target to a plethora of options. Biomed Res. Int. 2016, 2016, 1-12. [CrossRef]

58. Douillard, J.Y.; Siena, S.; Cassidy, J.; Tabernero, J.; Burkes, R.; Barugel, M.; Humblet, Y.; Bodoky, G.; Cunningham, D.; Jassem, J.; et al. Randomized, Phase III trial of panitumumab with infusional fluorouracil, leucovorin, and oxaliplatin (FOLFOX4) Versus FOLFOX4 alone as first-line treatment in patients with previously untreated metastatic colorectal cancer: The PRIME study. J. Clin. Oncol. 2010, 28, 4697-4705. [CrossRef]

59. Van Cutsem, E.; Köhne, C.-H.; Hitre, E.; Zaluski, J.; Chang Chien, C.-R.; Makhson, A.; D’Haens, G.; Pintér, T.; Lim, R.; Bodoky, G.; et al. Cetuximab and chemotherapy as initial treatment for metastatic colorectal cancer. N. Engl. J. Med. 2009, 360, 1408-1417. [CrossRef]

60. Douillard, J.-Y.; Oliner, K.S.; Siena, S.; Tabernero, J.; Burkes, R.; Barugel, M.; Humblet, Y.; Bodoky, G.; Cunningham, D.; Jassem, J.; et al. Panitumumab-FOLFOX4 Treatment and RAS Mutations in Colorectal Cancer. N. Engl. J. Med. 2013, 369, 1023-1034. [CrossRef]

61. Ursem, C.; Atreya, C.E.; Van Loon, K. Emerging treatment options for BRAF-mutant colorectal cancer. Gastrointest. Cancer Targets Ther. 2018, 8, 13-23. [CrossRef]

62. Di Nicolantonio, F.; Martini, M.; Molinari, F.; Sartore-Bianchi, A.; Arena, S.; Saletti, P.; De Dosso, S.; Mazzucchelli, L.; Frattini, M.; Siena, S.; et al. Wild-type BRAF is required for response to panitumumab or cetuximab in metastatic colorectal cancer. J. Clin. Oncol. 2008, 26, 5705-5712. [CrossRef] [PubMed]

63. Capper, D.; Voigt, A.; Bozukova, G.; Ahadova, A.; Kickingereder, P.; Von Deimling, A.; Von Knebel Doeberitz, M.; Kloor, M. BRAF V600E-specific immunohistochemistry for the exclusion of Lynch syndrome in MSI-H colorectal cancer. Int. J. Cancer 2013, 133, 1624-1630. [CrossRef] [PubMed]

64. Chen, W.; Swanson, B.J.; Frankel, W.L. Molecular genetics of microsatellite-unstable colorectal cancer for pathologists. Diagn. Pathol. 2017, 12, 24. [CrossRef] [PubMed] 
65. Tian, S.; Roepman, P.; Popovici, V.; Michaut, M.; Majewski, I.; Salazar, R.; Santos, C.; Rosenberg, R.; Nitsche, U.; Mesker, W.E.; et al. A robust genomic signature for the detection of colorectal cancer patients with microsatellite instability phenotype and high mutation frequency. J. Pathol. 2012, 228, 586-595. [CrossRef] [PubMed]

66. Roth, A.D.; Tejpar, S.; Delorenzi, M.; Yan, P.; Fiocca, R.; Klingbiel, D.; Dietrich, D.; Biesmans, B.; Bodoky, G.; Barone, C.; et al. Prognostic role of KRAS and BRAF in stage II and III resected colon cancer: Results of the translational study on the PETACC-3, EORTC 40993, SAKK 60-00 trial. J. Clin. Oncol. 2010, 28, 466-474. [CrossRef]

67. Manthravadi, S.; Sun, W.; Saeed, A. Prognostic impact of BRAF V600E mutation in patients with non-metastatic colorectal cancer with microsatellite instability: A systematic review and meta-analysis. J. Clin. Oncol. 2018, 15, 3597. [CrossRef]

68. Rosenbaum, M.W.; Bledsoe, J.R.; Morales-Oyarvide, V.; Huynh, T.G.; Mino-Kenudson, M. PD-L1 expression in colorectal cancer is associated with microsatellite instability, BRAF mutation, medullary morphology and cytotoxic tumor-infiltrating lymphocytes. Proc. Mod. Pathol. 2016, 29, 1104-1112. [CrossRef]

69. Lee, L.H.; Cavalcanti, M.S.; Segal, N.H.; Hechtman, J.F.; Weiser, M.R.; Smith, J.J.; Garcia-Aguilar, J.; Sadot, E.; Ntiamoah, P.; Markowitz, A.J.; et al. Patterns and prognostic relevance of PD-1 and PD-L1 expression in colorectal carcinoma. Mod. Pathol. 2016, 29, 1433-1442. [CrossRef]

70. Droeser, R.A.; Hirt, C.; Viehl, C.T.; Frey, D.M.; Nebiker, C.; Huber, X.; Zlobec, I.; Eppenberger-Castori, S.; Tzankov, A.; Rosso, R.; et al. Clinical impact of programmed cell death ligand 1 expression in colorectal cancer. Eur. J. Cancer 2013, 49, 2233-2242. [CrossRef]

71. Wang, H.B.; Yao, H.; Li, C.S.; Liang, L.X.; Zhang, Y.; Chen, Y.X.; Fang, J.Y.; Xu, J. Rise of PD-L1 expression during metastasis of colorectal cancer: Implications for immunotherapy. J. Dig. Dis. 2017, 18, 574-581. [CrossRef]

72. Llosa, N.J.; Cruise, M.; Tam, A.; Wicks, E.C.; Hechenbleikner, E.M.; Taube, J.M.; Blosser, R.L.; Fan, H.; Wang, H.; Luber, B.S.; et al. The vigorous immune microenvironment of microsatellite instable colon cancer is balanced by multiple counter-inhibitory checkpoints. Cancer Discov. 2015, 5, 43-51. [CrossRef] [PubMed]

73. Zhu, Y.F.; Yu, B.H.; Li, D.L.; Ke, H.L.; Guo, X.Z.; Xiao, X.Y. PI3K expression and PIK3CA mutations are related to colorectal cancer metastases. World J. Gastroenterol. 2012, 18, 3745-3751. [CrossRef] [PubMed]

74. Mao, C.; Yang, Z.Y.; Hu, X.F.; Chen, Q.; Tang, J.L. PIK3CA exon 20 mutations as a potential biomarker for resistance to anti-EGFR monoclonal antibodies in KRAS wild-type metastatic colorectal cancer: A systematic review and meta-analysis. Ann. Oncol. 2012, 23, 1518-1525. [CrossRef] [PubMed]

75. Prenen, H.; De Schutter, J.; Jacobs, B.; De Roock, W.; Biesmans, B.; Claes, B.; Lambrechts, D.; Van Cutsem, E.; Tejpar, S. PIK3CA mutations are not a major determinant of resistance to the epidermal growth factor receptor inhibitor cetuximab in metastatic colorectal cancer. Clin. Cancer Res. 2009, 15, 3184-3188. [CrossRef] [PubMed]

76. Alvarez-Garcia, V.; Bartos, C.; Keraite, I.; Trivedi, U.; Brennan, P.M.; Kersaudy-Kerhoas, M.; Gharbi, K.; Oikonomidou, O.; Leslie, N.R. A simple and robust real-time qPCR method for the detection of PIK3CA mutations. Sci. Rep. 2018, 8, 4290. [CrossRef]

77. Yazdani, Y.; Farazmandfar, T.; Azadeh, H.; Zekavatian, Z. The prognostic effect of PTEN expression status in colorectal cancer development and evaluation of factors affecting it: MiR-21 and promoter methylation. J. Biomed. Sci. 2016, 23, 9. [CrossRef]

78. Negri, F.V.; Bozzetti, C.; Lagrasta, C.A.; Crafa, P.; Bonasoni, M.P.; Camisa, R.; Pedrazzi, G.; Ardizzoni, A. PTEN status in advanced colorectal cancer treated with cetuximab. Br. J. Cancer 2010, 102, 162-164. [CrossRef]

79. Laurent-Puig, P.; Cayre, A.; Manceau, G.; Buc, E.; Bachet, J.B.; Lecomte, T.; Rougier, P.; Lievre, A.; Landi, B.; Boige, V.; et al. Analysis of PTEN, BRAF, and EGFR status in determining benefit from cetuximab therapy in wild-type KRAS metastatic colon cancer. J. Clin. Oncol. 2009, 27, 5924-5930. [CrossRef]

80. Loupakis, F.; Pollina, L.; Stasi, I.; Ruzzo, A.; Scartozzi, M.; Santini, D.; Masi, G.; Graziano, F.; Cremolini, C.; Rulli, E.; et al. PTEN expression and KRAS mutations on primary tumors and metastases in the prediction of benefit from cetuximab plus irinotecan for patients with metastatic colorectal cancer. J. Clin. Oncol. 2009, 27, 2622-2629. [CrossRef]

81. Bohn, B.A.; Mina, S.; Krohn, A.; Simon, R.; Kluth, M.; Harasimowicz, S.; Quaas, A.; Bockhorn, M.; Izbicki, J.R.; Sauter, G.; et al. Altered PTEN function caused by deletion or gene disruption is associated with poor prognosis in rectal but not in colon cancer. Hum. Pathol. 2013, 44, 1524-1533. [CrossRef]

82. Atreya, C.E.; Sangale, Z.; Xu, N.; Matli, M.R.; Tikishvili, E.; Welbourn, W.; Stone, S.; Shokat, K.M.; Warren, R.S. PTEN expression is consistent in colorectal cancer primaries and metastases and associates with patient survival. Cancer Med. 2013, 2, 496-506. [CrossRef] [PubMed] 
83. Eklöf, V.; Wikberg, M.L.; Edin, S.; Dahlin, A.M.; Jonsson, B.A.; Öberg, Å.; Rutegård, J.; Palmqvist, R. The prognostic role of KRAS, BRAF, PIK3CA and PTEN in colorectal cancer. Br. J. Cancer 2013, 108, 2153-2163. [CrossRef] [PubMed]

84. Day, F.L.; Jorissen, R.N.; Lipton, L.; Mouradov, D.; Sakthianandeswaren, A.; Christie, M.; Li, S.; Tsui, C.; Tie, J.; Desai, J.; et al. PIK3CA and PTEN gene and exon mutation-specific clinicopathologic and molecular associations in colorectal cancer. Clin. Cancer Res. 2013, 19, 3285-3296. [CrossRef] [PubMed]

85. Pazhoomand, R.; Keyhani, E.; Banan, M.; Najmabadi, H.; Khodadadi, F.; Iraniparast, A.; Feiz, F.; Majidzadeh, K.; Bahman, I.; Moghadam, F.A.; et al. Detection of HER2 status in breast cancer: Comparison of current methods with MLPA and real-time RT-PCR. Asian Pac. J. Cancer Prev. 2013, 14, 7621-7628. [CrossRef]

86. Valtorta, E.; Martino, C.; Sartore-Bianchi, A.; Penaullt-Llorca, F.; Viale, G.; Risio, M.; Rugge, M.; Grigioni, W.; Bencardino, K.; Lonardi, S.; et al. Assessment of a HER2 scoring system for colorectal cancer: Results from a validation study. Mod. Pathol. 2015, 28, 1481-1491. [CrossRef]

87. Muzny, D.M.; Bainbridge, M.N.; Chang, K.; Dinh, H.H.; Drummond, J.A.; Fowler, G.; Kovar, C.L.; Lewis, L.R.; Morgan, M.B.; Newsham, I.F.; et al. Comprehensive molecular characterization of human colon and rectal cancer. Nature 2012, 487, 330-337. [CrossRef]

88. Sartore-Bianchi, A.; Trusolino, L.; Martino, C.; Bencardino, K.; Lonardi, S.; Bergamo, F.; Zagonel, V.; Leone, F.; Depetris, I.; Martinelli, E.; et al. Dual-targeted therapy with trastuzumab and lapatinib in treatment-refractory, KRAS codon 12/13 wild-type, HER2-positive metastatic colorectal cancer (HERACLES): A proof-of-concept, multicentre, open-label, phase 2 trial. Lancet Oncol. 2016, 17, 738-746. [CrossRef]

89. Schepeler, T.; Reinert, J.T.; Ostenfeld, M.S.; Christensen, L.L.; Silahtaroglu, A.N.; Dyrskjøt, L.; Wiuf, C.; Sørensen, F.J.; Kruhøffer, M.; Laurberg, S.; et al. Diagnostic and prognostic microRNAs in stage II colon cancer. Cancer Res. 2008, 68, 6416-6424. [CrossRef]

90. Nagel, R.; Le Sage, C.; Diosdado, B.; Van Der Waal, M.; Oude Vrielink, J.A.F.; Bolijn, A.; Meijer, G.A.; Agami, R. Regulation of the adenomatous polyposis coli gene by the miR-135 family in colorectal cancer. Cancer Res. 2008, 68, 5795-5802. [CrossRef]

91. Kan, S.F.; Yang, J.S.; Sun, G.X.; Sun, J.J. MicroRNA-135b is associated with tumor progression in colorectal cancer. Int. J. Clin. Exp. Med. 2016, 9, 6533-6538.

92. Zhou, W.; Li, X.; Liu, F.; Xiao, Z.; He, M.; Shen, S.; Liu, S. MiR-135a promotes growth and invasion of colorectal cancer via metastasis suppressor 1 in vitro. Acta Biochim. Biophys. Sin. 2012, 44, 838-846. [CrossRef] [PubMed]

93. Lu, D.; Tang, L.; Zhuang, Y.; Zhao, P. MiR-17-3P regulates the proliferation and survival of colon cancer cells by targeting Par4. Mol. Med. Rep. 2018, 17, 618-623. [CrossRef] [PubMed]

94. Chen, E.; Li, Q.; Wang, H.; Yang, F.; Min, L.; Yang, J. MiR-92a promotes tumorigenesis of colorectal cancer, a transcriptomic and functional based study. Biomed. Pharmacother. 2018, 106, 1370-1377. [CrossRef]

95. Yang, X.; Zeng, Z.; Hou, Y.; Yuan, T.; Gao, C.; Jia, W.; Yi, X.; Liu, M. MicroRNA-92a as a potential biomarker in diagnosis of colorectal cancer: A systematic review and meta-analysis. PLoS One 2014, 9, e88745. [CrossRef]

96. Pu, X.X.; Huang, G.L.; Guo, H.Q.; Guo, C.C.; Li, H.; Ye, S.; Ling, S.; Jiang, L.; Tian, Y.; Lin, T.Y. Circulating miR-221 directly amplified from plasma is a potential diagnostic and prognostic marker of colorectal cancer and is correlated with p53 expression. J. Gastroenterol. Hepatol. 2010, 25, 1674-1680. [CrossRef] [PubMed]

97. Dong, Y.; Zhao, J.; Wu, C.-W.; Zhang, L.; Liu, X.; Kang, W.; Leung, W.-W.; Zhang, N.; Chan, F.K.L.; Sung, J.J.Y.; et al. Tumor suppressor functions of miR-133a in colorectal cancer. Mol. Cancer Res. 2013, 11, 1051-1060. [CrossRef]

98. Guinney, J.; Dienstmann, R.; Wang, X.; De Reyniès, A.; Schlicker, A.; Soneson, C.; Marisa, L.; Roepman, P.; Nyamundanda, G.; Angelino, P.; et al. The consensus molecular subtypes of colorectal cancer. Nat. Med. 2015, 21, 1350-1356. [CrossRef]

99. Williams, D.S.; Mouradov, D.; Jorissen, R.N.; Newman, M.R.; Amini, E.; Nickless, D.K.; Teague, J.A.; Fang, C.G.; Palmieri, M.; Parsons, M.J.; et al. Lymphocytic response to tumour and deficient DNA mismatch repair identify subtypes of stage II/III colorectal cancer associated with patient outcomes. Gut 2019, 68, 465-474. [CrossRef]

100. Marisa, L.; Ayadi, M.; Balogoun, R.; Pilati, C.; Le Malicot, K.; Lepage, C.; Emile, J.-F.; Salazar, R.; Aust, D.E.; Duval, A.; et al. Clinical utility of colon cancer molecular subtypes: Validation of two main colorectal molecular classifications on the PETACC-8 phase III trial cohort. J. Clin. Oncol. 2017, 15, 3509. [CrossRef] 
101. Mooi, J.K.; Wirapati, P.; Asher, R.; Lee, C.K.; Savas, P.; Price, T.J.; Townsend, A.; Hardingham, J.; Buchanan, D.; Williams, D.; et al. The prognostic impact of consensus molecular subtypes (CMS) and its predictive effects for bevacizumab benefit in metastatic colorectal cancer: Molecular analysis of the AGITG MAX clinical trial. Ann. Oncol. 2018, 29, 2240-2246. [CrossRef]

102. Lenz, H.-J.; Ou, F.-S.; Venook, A.P.; Hochster, H.S.; Niedzwiecki, D.; Goldberg, R.M.; Mayer, R.J.; Bertagnolli, M.M.; Blanke, C.D.; Zemla, T.; et al. Impact of consensus molecular subtype on survival in patients with metastatic colorectal cancer: results from CALGB/SWOG 80405 (Alliance). J. Clin. Oncol. 2019, 37, 1876-1885. [CrossRef] [PubMed]

103. Okita, A.; Takahashi, S.; Ouchi, K.; Inoue, M.; Watanabe, M.; Endo, M.; Honda, H.; Yamada, Y.; Ishioka, C. Consensus molecular subtypes classification of colorectal cancer as a predictive factor for chemotherapeutic efficacy against metastatic colorectal cancer. Oncotarget 2018, 9, 18698-18711. [CrossRef] [PubMed]

104. Smith, R.A.; Andrews, K.S.; Brooks, D.; Fedewa, S.A.; Manassaram-Baptiste, D.; Saslow, D.; Brawley, O.W.; Wender, R.C. Cancer screening in the United States, 2018: A review of current American Cancer Society guidelines and current issues in cancer screening. CA Cancer J. Clin. 2018, 68, 297-316. [CrossRef] [PubMed]

105. Sargent, D.J.; Marsoni, S.; Monges, G.; Thibodeau, S.N.; Labianca, R.; Hamilton, S.R.; French, A.J.; Kabat, B.; Foster, N.R.; Torri, V.; et al. Defective mismatch repair as a predictive marker for lack of efficacy of fluorouracil-based adjuvant therapy in colon cancer. J. Clin. Oncol. 2010, 28, 3219-3226. [CrossRef] [PubMed]

106. Chen, G.; Yang, Z.; Eshleman, J.R.; Netto, G.J.; Lin, M.T. Molecular diagnostics for precision medicine in colorectal cancer: Current status and future perspective. BioMed Res. Int. 2016, 2016, 9850690. [CrossRef]

107. Cree, I.A. Diagnostic RAS mutation analysis by polymerase chain reaction (PCR). Biomol. Detect. Quantif. 2016, 8, 29-32. [CrossRef]

108. Garcia, J.; Forestier, J.; Dusserre, E.; Wozny, A.-S.; Geiguer, F.; Merle, P.; Tissot, C.; Ferraro-Peyret, C.; Jones, F.S.; Edelstein, D.L.; et al. Cross-platform comparison for the detection of RAS mutations in cfDNA (ddPCR Biorad detection assay, BEAMing assay, and NGS strategy). Oncotarget 2018, 9, 21122-21131. [CrossRef]

109. Neumann, J.; Zeindl-Eberhart, E.; Kirchner, T.; Jung, A. Frequency and type of KRAS mutations in routine diagnostic analysis of metastatic colorectal cancer. Pathol. Res. Pract. 2009, 205, 858-862. [CrossRef]

110. Tsiatis, A.C.; Norris-Kirby, A.; Rich, R.G.; Hafez, M.J.; Gocke, C.D.; Eshleman, J.R.; Murphy, K.M. Comparison of Sanger sequencing, pyrosequencing, and melting curve analysis for the detection of KRAS mutations: Diagnostic and clinical implications. J. Mol. Diagn. 2010, 12, 425-432. [CrossRef]

111. Szankasi, P.; Reading, N.S.; Vaughn, C.P.; Prchal, J.T.; Bahler, D.W.; Kelley, T.W. A quantitative allele-specific PCR test for the BRAF V600E mutation using a single heterozygous control plasmid for quantitation: A model for qPCR testing without standard curves. J. Mol. Diagn. 2013, 15, 248-254. [CrossRef]

112. Do, H.; Krypuy, M.; Mitchell, P.L.; Fox, S.B.; Dobrovic, A. High resolution melting analysis for rapid and sensitive EGFR and KRAS mutation detection in formalin fixed paraffin embedded biopsies. BMC Cancer 2008, 8, 142. [CrossRef] [PubMed]

113. Oliner, K.; Juan, T.; Suggs, S.; Wolf, M.; Sarosi, I.; Freeman, D.J.; Gyuris, T.; Baron, W.; Bakker, A.; Parker, A.; et al. A comparability study of 5 commercial KRAS tests. Diagn. Pathol. 2010, 5, 23. [CrossRef] [PubMed]

114. Kobunai, T.; Watanabe, T.; Yamamoto, Y.; Eshima, K. The frequency of KRAS mutation detection in human colon carcinoma is influenced by the sensitivity of assay methodology: A comparison between direct sequencing and real-time PCR. Biochem. Biophys. Res. Commun. 2010, 395, 158-162. [CrossRef] [PubMed]

115. Sarasqueta, A.F.; Moerland, E.; De Bruyne, H.; De Graaf, H.; Vrancken, T.; Van Lijnschoten, G.; Van Den Brule, A.J.C. SNaPshot and StripAssay as valuable alternatives to direct sequencing for KRAS mutation detection in colon cancer routine diagnostics. J. Mol. Diagn. 2011, 13, 199-205. [CrossRef]

116. Halait, H.; Demartin, K.; Shah, S.; Soviero, S.; Langland, R.; Cheng, S.; Hillman, G.; Wu, L.; Lawrence, H.J. Analytical performance of a real-time PCR-based assay for V600 mutations in the BRAF gene, used as the companion diagnostic test for the novel BRAF inhibitor vemurafenib in metastatic melanoma. Diagn. Mol. Pathol. 2012, 21, 1-8. [CrossRef]

117. Harbison, C.T.; Horak, C.E.; Ledeine, J.M.; Mukhopadhyay, P.; Malone, D.P.; O'Callaghan, C.; Jonker, D.J.; Karapetis, C.S.; Khambata-Ford, S.; Gustafson, N.; et al. Validation of companion diagnostic for detection of mutations in Codons 12 and 13 of the KRAS gene in patients with metastatic colorectal Cancer: Analysis of the NCIC CTG CO.17 trial. Arch. Pathol. Lab. Med. 2013, 137, 820-827. [CrossRef] 
118. Harlé, A.; Busser, B.; Rouyer, M.; Harter, V.; Genin, P.; Leroux, A.; Merlin, J.L. Comparison of COBAS 4800 KRAS, TaqMan PCR and High Resolution Melting PCR assays for the detection of KRAS somatic mutations in formalin-fixed paraffin embedded colorectal carcinomas. Virchows Arch. 2013, 462, 329-335. [CrossRef]

119. Nordgård, O.; Oltedal, S.; Janssen, E.A.M.; Gilje, B.; Kørner, H.; Tjensvoll, K.; Smaaland, R. Comparison of a PNA clamp PCR and an ARMS/Scorpion PCR assay for the detection of K-ras mutations. Diagn. Mol. Pathol. 2012, 21, 9-13. [CrossRef]

120. Orum, H. PCR clamping. Curr. Issues Mol. Biol. 2000, 2, 27-30. [CrossRef]

121. Mancini, I.; Santucci, C.; Sestini, R.; Simi, L.; Pratesi, N.; Cianchi, F.; Valanzano, R.; Pinzani, P.; Orlando, C. The use of COLD-PCR and high-resolution melting analysis improves the limit of detection of KRAS and BRAF mutations in colorectal cancer. J. Mol. Diagnostics 2010, 12, 705-711. [CrossRef]

122. Solassol, J.; Vendrell, J.; Märkl, B.; Haas, C.; Bellosillo, B.; Montagut, C.; Smith, M.; O'Sullivan, B.; D’Haene, N.; Le Mercier, M.; et al. Multi-center evaluation of the fully automated PCR-based Idylla ${ }^{\mathrm{TM}}$ KRAS mutation assay for rapid KRAS mutation status determination on formalin-fixed paraffin-embedded tissue of human colorectal cancer. PLoS One 2016, 11, e0163444. [CrossRef] [PubMed]

123. Johnston, L.; Power, M.; Sloan, P.; Long, A.; Silmon, A.; Chaffey, B.; Lisgo, A.J.; Little, L.; Vercauteren, E.; Steiniche, T.; et al. Clinical performance evaluation of the Idylla NRAS-BRAF mutation test on retrospectively collected formalin-fixed paraffin-embedded colorectal cancer tissue. J. Clin. Pathol. 2018, 71, 336-343. [CrossRef] [PubMed]

124. Lewandowska, M.A.; Jóåwicki, W.; Żurawski, B. KRAS and BRAF mutation analysis in colorectal adenocarcinoma specimens with a low percentage of tumor cells. Mol. Diagn. Ther. 2013, 17, 193-203. [CrossRef] [PubMed]

125. Magnin, S.; Viel, E.; Baraquin, A.; Valmary-Degano, S.; Kantelip, B.; Pretet, J.L.; Mougin, C.; Bigand, M.; Girardo, B.; Borg, C.; et al. A multiplex SNaPshot assay as a rapid method for detecting KRAS and BRAF mutations in advanced colorectal cancers. J. Mol. Diagn. 2011, 13, 485-492. [CrossRef] [PubMed]

126. Denis, J.A.; Patroni, A.; Guillerm, E.; Pépin, D.; Benali-Furet, N.; Wechsler, J.; Manceau, G.; Bernard, M.; Coulet, F.; Larsen, A.K.; et al. Droplet digital PCR of circulating tumor cells from colorectal cancer patients can predict KRAS mutations before surgery. Mol. Oncol. 2016, 10, 1221-1231. [CrossRef] [PubMed]

127. Neumann, M.H.D.; Bender, S.; Krahn, T.; Schlange, T. ctDNA and CTCs in liquid biopsy-Current status and where we need to progress. Comput. Struct. Biotechnol. J. 2018, 16, 190-195. [CrossRef]

128. Baudrin, L.G.; Deleuze, J.F.; How-Kit, A. Molecular and computational methods for the detection of microsatellite instability in cancer. Front. Oncol. 2018, 8, 621. [CrossRef]

129. Redford, L.; Alhilal, G.; Needham, S.; O’Brien, O.; Coaker, J.; Tyson, J.; Amorim, L.M.; Middleton, I.; Izuogu, O.; Arends, M.; et al. A novel panel of short mononucleotide repeats linked to informative polymorphisms enabling effective high volume low cost discrimination between mismatch repair deficient and proficient tumours. PLoS One 2018, 13, e0203052. [CrossRef]

130. Murphy, K.M.; Zhang, S.; Geiger, T.; Hafez, M.J.; Bacher, J.; Berg, K.D.; Eshleman, J.R. Comparison of the microsatellite instability analysis system and the Bethesda panel for the determination of microsatellite instability in colorectal cancers. J. Mol. Diagn. 2006, 8, 305-311. [CrossRef]

131. Babaei, H.; Zeinalian, M.; Emami, M.H.; Hashemzadeh, M.; Farahani, N.; Salehi, R. Simplified microsatellite instability detection protocol provides equivalent sensitivity to robust detection strategies in Lynch syndrome patients. Cancer Biol. Med. 2017, 14, 142-150. [CrossRef]

132. Chen, C.; Ridzon, D.A.; Broomer, A.J.; Zhou, Z.; Lee, D.H.; Nguyen, J.T.; Barbisin, M.; Xu, N.L.; Mahuvakar, V.R.; Andersen, M.R.; et al. Real-time quantification of microRNAs by stem-loop RT-PCR. Nucleic Acids Res. 2005, 33, e179. [CrossRef] [PubMed]

133. Li, W.; Ruan, K. MicroRNA detection by microarray. Anal. Bioanal. Chem. 2009, 394, 1117-1124. [CrossRef] [PubMed]

134. Hou, S.Y.; Hsiao, Y.L.; Lin, M.S.; Yen, C.C.; Chang, C.S. MicroRNA detection using lateral flow nucleic acid strips with gold nanoparticles. Talanta 2012, 99, 375-379. [CrossRef] [PubMed]

135. Mao, X.; Xu, H.; Zeng, Q.; Zeng, L.; Liu, G. Molecular beacon-functionalized gold nanoparticles as probes in dry-reagent strip biosensor for DNA analysis. Chem. Commun. 2009, 21, 3065-3067. [CrossRef]

136. He, Y.; Zhang, S.; Zhang, X.; Baloda, M.; Gurung, A.S.; Xu, H.; Zhang, X.; Liu, G. Ultrasensitive nucleic acid biosensor based on enzyme-gold nanoparticle dual label and lateral flow strip biosensor. Biosens. Bioelectron. 2011, 26, 2018-2024. [CrossRef]

137. Aravanis, A.M.; Lee, M.; Klausner, R.D. Next-generation sequencing of circulating tumor DNA for early cancer detection. Cell 2017, 168, 571-574. [CrossRef] 
138. Marcuello, M.; Vymetalkova, V.; Neves, R.P.L.; Duran-Sanchon, S.; Vedeld, H.M.; Tham, E.; van Dalum, G.; Flügen, G.; Garcia-Barberan, V.; Fijneman, R.J.; et al. Circulating biomarkers for early detection and clinical management of colorectal cancer. Mol. Asp. Med. 2019, 69, 107-122. [CrossRef]

139. Andrews, D.; Chetty, Y.; Cooper, B.S.; Virk, M.; Glass, S.K.; Letters, A.; Kelly, P.A.; Sudhanva, M.; Jeyaratnam, D. Multiplex PCR point of care testing versus routine, laboratory-based testing in the treatment of adults with respiratory tract infections: A quasi-randomised study assessing impact on length of stay and antimicrobial use. BMC Infect. Dis. 2017, 17, 671. [CrossRef]

140. Lindeman, N.I.; Cagle, P.T.; Beasley, M.B.; Chitale, D.A.; Dacic, S.; Giaccone, G.; Jenkins, R.B.; Kwiatkowski, D.J.; Saldivar, J.S.; Squire, J.; et al. Molecular testing guideline for selection of lung cancer patients for EGFR and ALK tyrosine kinase inhibitors: Guideline from the College of American Pathologists, International Association for the Study of Lung Cancer, and Association for Molecular Patho. J. Thorac. Oncol. 2013, 8, 823-859. [CrossRef]

(C) 2019 by the authors. Licensee MDPI, Basel, Switzerland. This article is an open access article distributed under the terms and conditions of the Creative Commons Attribution (CC BY) license (http://creativecommons.org/licenses/by/4.0/). 